DOI: $10.7242 / 1998-2097 / 2018.4 .7$

УДК 633.1:(470.53)

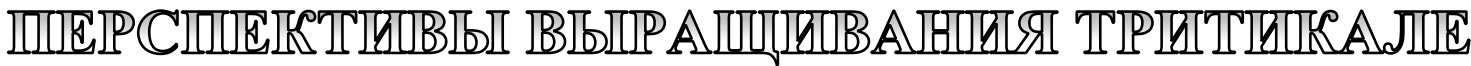

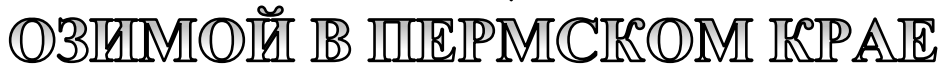

Г.П. Майсак, Пермский научно-исследовательский институт сельского хозяйства

Приведена краткая историческая справка создания новой культуры тритикале озимой. Описаны перспективы возделывания и использования тритикале озимой в Пермском крае. В течение 2006-2016 годов разработаны технологии возделывания тритикале озимой на корм и зерно в одновидовых и смешанных агрофитоценозах, для приготовления силоса и зерносенажа. Установлено, что тритикале озимая - перспективная культура, может с успехом возделываться в Пермском крае, использоваться на зеленый корм, для заготовки силоса и зерносенажа, формируя высокую урожайность как зелёной до 24,5 т/га, так и сухой массы - 5,96 т/га, зерна - 5,46 т/га. Заготовка силоса из свежескошенной зелёной массы озимых культур в начале колошения, зерносенажа в молочно-восковую спелость обеспечивают получение корма I-II класса с содержанием сырого протеина - 9,23-18,01\%, обменной энергии 8,73-10,94 МДж/кг, кормовых единиц - 0,63-0,97 на абсолютно сухое вещество.

Ключевые слова: тритикале озимая, урожайность, зеленая масса, сухая масса, зерно, силос, зерносенаж.

Как отмечал К.А.Тимирязев, «существуют вопросы, которые всегда вызывают живой интерес и на которые не существует моды. Таков вопрос о насущном хлебе». Данный подход не устарел до сих пор. Обеспечение населения зерном (хлебом) - проблема всего человечества, и надо искать пути её решения [16]. Один из таких путей - увеличение производства тритикале озимой - первой зерновой культуры, созданной человеком, что является одним из крупнейших достижений селекции за последние десятилетия. Селекционерам удалось синтезировать новую сельскохозяйственную культуру, объединяющую в одном организме все ценное исходных родов: пшеницы и ржи. По мнению многих ученых, в недалеком будущем тритикале станет одной из ведущих зерновых культур, а также будет возделываться на зеленый корм [21].

$\begin{array}{ccc}\text { Историю } & \text { и этапы } \\ \text { этой } & \text { появления } \\ & \text { культры } & \text { описывают }\end{array}$

Ю.Л. Гужов (1978) [21], П.Ф. Медведев, А.И. Сметанникова (1981) [12], А.И. Грабовец (2018) [7]. Термин «тритикале» впервые предложил E. Tschermak в 1931 году, он возник из сочетания родовых названий родительских видов Triticum и Secale. Однако сама тритикале впервые была создана А.С. Вильсоном (Шотландия, A.S. Wilson, 1876). Первый фертильный октаплоидный амфидиплоид в 1888 г. выявил W.Rimpau (1891) из гибридной популяции - местной саксонской пшеницы + ржи Шланштедская. L.Wittmak (1899) впервые попытался определиться с классификацией тритикале. В настояшее время тритикале считается самостоятельным ботаническим родом тритикале (x Triticosecale Wittmack ex A.Camus). 
В истории гибридизации пшеницы с рожью большое значение имеют исследования отечественных учёных. Г.К. Мейстер на Саратовской сельскохозяйственной опытной станции наблюдал образование таких гибридов в посевах ржи при спонтанной гибридизации ее с пшеницей. В 1925 г. В.Н. Лебедевым на Белоцерковской опытно-селекционной станции были найдены естественные ржано-пшеничные гибриды. В.Е. Писаревым в НИИСХ ЦР Нечернозёмной зоны путем скрещивания мягкой пшеницы с яровой рожью были получены октаплоидные 56 - хромосомные тритикале, которые оказались исключительно ценными по зимостойкости.

Гексаплоидные 42-хромосомные Triticale создаются в результате скрещивания твердой пшеницы с рожью. Гексаплоидные гибриды тритикале представляют большую практическую ценность. Они имеют высокую озернённость колоса, высокую продуктивность, содержат больше белка, чем октаплоидные гибриды.

Одним из пионеров в области изучения гексаплоидных тритикале был А.И. Державин, который в 1932 г. получил первый амфидиплоид от скрещивания твердой пшеницы с рожью. После этого появился большой интерес к этим гибридам в СССР, Венгрии, Испании, Болгарии, Польше и других странах мира.

На территории бывшего Советского Союза озимую тритикале с успехом возделывали от Северного Кавказа и Ставрополья на юге $[10,13]$ до Центральных районов черноземья и Московской области - на севере [3, 8]; от Белоруссии [19] и Украины - на западе [11] до Сахалина на востоке [22].

В настоящее время ведущим селекционным центром по созданию сортов тритикале является Федеральный Ростовский аграрный центр (ДЗНИИСХ). С 1974 по 2017 год им создано 35 сортов озимой тритикале. В гостреестр селекционных достижений, допущенных к использованию в производстве, включено 25 сортов. В Федеральном научном центре зерна им.
П.П. Лукьяненко (Краснодар) разрешено к использованию в 2018 году 14 сортов, НИИСХЧП им. В.В. Докучаева - 3 сорта, НИИСХ ЦРНЗ - 4 сорта, Ставропольский НИИСХ - 3 сорта, ВНИИР и др. [5, 7].

В последние годы в России, наряду с традиционно возделываемыми озимыми культурами, во многих регионах страны увеличиваются посевы тритикале. Интерес к тритикале возрастает в силу уникального сочетания ряда хозяйственно-биологических особенностей новой зерновой и кормовой культуры. Эта культура универсального использования. Зерно тритикале пригодно для хлебопечения, получения крахмала, спирта, откорма сельскохозяйственных животных. Ее зеленая масса используется для получения раннего высококачественного зеленого корма, приготовления гранул, силоса, сенажа, зерносенажа.

В настоящее время заявило о себе новое направление в селекции тритикале - создание генотипов с содержанием каротиноидов на уровне яровой твердой пшеницы или выше (более 400 мг $\%$ ), с высоким содержанием крахмала (65-72\%), белка в зерне - более $14 \%$. Разработаны технологии приготовления муки, различных круп, хлопьев. Создана группа сортов, предназначенных специально для возделывания на корм с продуктивностью в оптимальных условиях до 100 т/га зеленой массы, не требующих пестицидного перекрытия $[6,7]$.

Первые исследования по тритикале озимой в Пермском НИИСХ проведены в 2002 году в коллекционном питомнике кормовых культур. Культура зарекомендовала себя перспективной. В испытании было два сорта тритикале озимой (Ставропольский 1 и Алтайский 1 ), которые обеспечили урожайность зелёной массы соответственно 22,0 и 16,0 т/га, сухой 4,93 и 3,38 т/га.

Известно, что в комплексе агротехнических мероприятий, направленных на получение высоких и устойчивых урожаев любой сельскохозяйственной культуры, в том числе и тритикале, большое значение имеет подбор сортов. Успех технологии 
выращивания любой сельскохозяйственной культуры на 30-70\% зависит от правильно подобранного сорта [9].

С 2006 по 2010 год в Пермском НИИСХ проведена сравнительная оценка 7 сортов тритикале на корм и зерно. Все изучаемые сорта в среднем за годы испытаний обеспечили высокую урожайность зеленой массы - до 24,5, сбор сухой массы до 5,96 т/га, зерна - до 5,46 т/га. Максимальную урожайность зеленой массы обеспечил сорт Ставропольский 5 в смеси с озимой викой $(38,8$ т/га), зерна - сорт Цекад 90 (7,18 т/га). В среднем за 20122017 гг. на сортоучастках Пермского края получена урожайность зерна тритикале 3,64 т/га, что на 0,95 т/га выше озимой пшеницы и 0,50 т/га - озимой ржи. В коллекционном питомнике Пермского НИИСХ с 2012 по 2016 год проводилась комплексная оценка 17 сортов озимой тритикале на зерно различного экологогеографического происхождения по хозяйственно-ценным признакам. Установлено, что из 17 изучаемых сортов озимой тритикале высокую биологическую урожайность зерна обеспечили 16, сформировав в среднем от 5,47 до 9,30 т/га зерна.

В повышении продуктивности животных большое значение отводится обеспечению кормами в ранневесенний период. Одними из основных источников корма в этот период являются озимые культуры (рисунок).
Зелёная масса кормовых сортов тритикале содержит почти в три раза больше каротина и в 1,5-2,0 раза - сахара, чем зелёная масса ржи, медленнее грубеет и дольше не теряет кормовые достоинства [10]. Возделывание озимых культур совместно с озимой викой позволяет без сокращения площадей под другими культурами увеличить производство кормов на 20-30\% и улучшить их качество в 1,4-1,5 раза [20]. Аналогичные данные получены и в исследованиях, проведенных Пермским НИИСХ в 2001-2005 годах, добавление к озимой ржи от 1 до 5 млн всхожих семян/га вики повышало содержание сырого протеина с 12,92 до 20,04-22,59 \%, концентрацию обменной энергии с 9,28 до 10,03-10,47 МДж/кг абсолютно сухого вещества [4].

С 2006 года в Пермском НИИСХ началась разработка вариантов технологий возделывания тритикале озимой на корм и зерно; в совместных посевах с озимой викой с использованием поукосных посевов проса и рапса ярового, экспериментальными данными установлено, что тритикале озимая может успешно возделываться в Пермском крае, как в одновидовых, так и двухкомпонентных смесях. Данные культуры формируют самый ранний зелёный корм - с конца третьей декады мая до середины июня; обеспечивают высокую урожайность: зелёной массы в фазе начала колошения - до 24,5 т/га, сухого вещества -

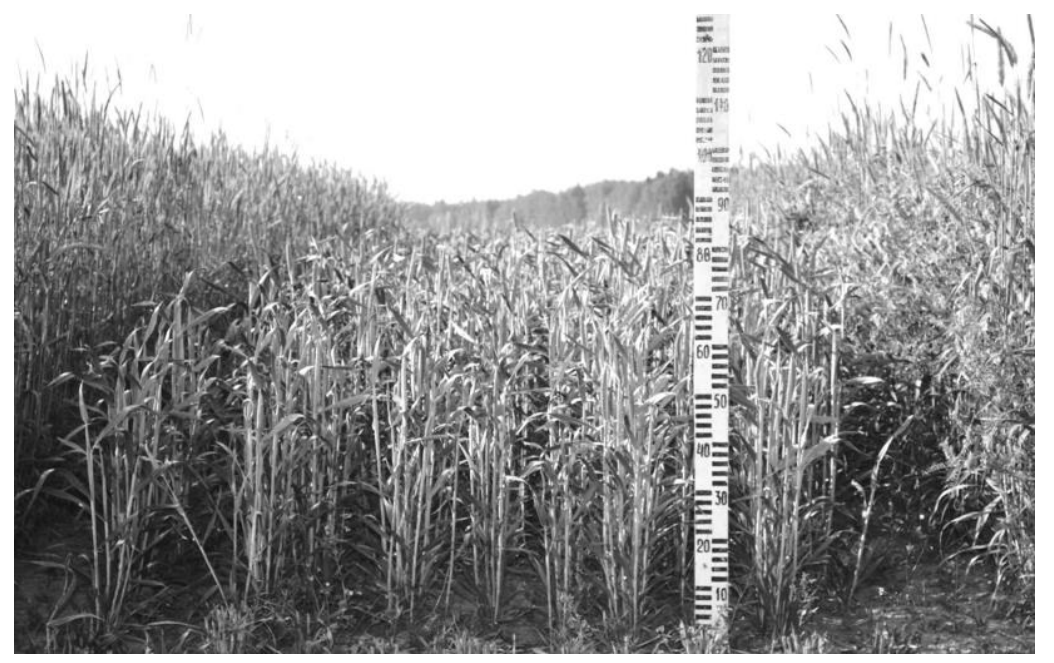

Рис. Озимые культуры: рожь Фалёнская 4 (слева), тритикале СИРС 57 (в цеентре), рожь +вика (справа) 
до 5,96 т/га; зерна - до 5,46 т/га; позволяют получать зелёную массу с концентрацией обменной энергии от 10 до 12 МДж/кг сухого вещества. Кроме того, использование озимых культур для заготовки кормов позволяет раньше начать эту кампанию и тем самым снизить нагрузку на технику в пиковые периоды сельскохозяйственных работ, подбирая разные сорта по скороспелости, обеспечить конвейерное поступление зелёной массы $[14,15]$.

В период с 2011 по 2016 год сотрудниками отдела кормопроизводства прорабатывались вопросы заготовки силоса и зерносенажа из озимых культур. Результатами исследований установлено, что возделываемые в Пермском крае озимые культуры могут с успехом использоваться на силос и зерносенаж, формируя высокую урожайность как зелёной - 16,2-20,1 т/га, так и сухой массы - 3,38-8,27 т/га. Заготовка силоса из свежескошенной зелёной массы озимых культур в начале колошения обеспечивает получение корма I-II класса (ГОСТ55986-2014) с содержанием сухого вещества 203,0-255,5 г, сырого протеина $136,0-180,1$ г, обменной энергии - 9,6510,94 МДж, кормовых единиц - 0,76-0,97 на 1 кг абсолютно сухого вещества.

Заготовка зерносенажа из свежескошенной зелёной массы озимых культур в молочно-восковую спелость зерна обеспечивает получение корма в основном II класса (ОСТ 10 029-94) с содержанием сухого вещества $36,98-44,34 \%$, сырого протеина - 9,23-11,49\%, обменной энергии - 8,73-9,21 МДж/кг, кормовых единиц - 0,63-0,69 на абсолютно сухое вещество; коэффициент энергетической эффективности при этом - 5,0-5,6.

Нами определены технологические свойства зерна четырёх сортов тритикале, качество муки и хлебопекарная оценка качества хлеба из муки тритикале (таблица) по методике Государственного сортоиспытания сельскохозяйственных культур [17]. Результаты исследований получены на Красноуфимской селекционной станции Государственного научного уч- реждения Уральский НИИСХ.

Натурный вес характеризует выполненность зерна. Чем выше натурный вес зерна, тем больше его масса в единице объёма. Такое зерно богаче полезными веществами, в нем больше эндосперма и, соответственно, меньше оболочек. Из высоконатурного зерна больше выход муки [1].

Сорт Антей имеет самую высокую натуру - 721 г/л. У других сортов она ниже на 16-21 г/л, выше по сравнению с пшеницей яровой, выращенной на Куединской ГСУ, - на 28-69 г. Однако, несмотря на небольшие колебания по натурному весу зерна тритикале, выход муки получился ровным у всех сортов $-67 \%$.

Стекловидность (консистенция) зерна один из основных признаков его мукомольных свойств. Как правило, в пределах одного сорта более стекловидное зерно лучше размалывается, дает больший выход крупок и муки высоких сортов [22]. Высокостекловидным считается зерно пшеницы с общим показателем - свыше $60 \%$, среднее по стекловидности - от 40 до 60\%, низкостекловидное - менее $40 \%$.

В наших исследованиях сорт Антей сформировал высокостекловидное зерно $78 \%$, сорта Гермес, Доктрина 110 и Цекад 90 - среднее по стекловидности 54-58\%. По данным Куединской ГСУ, стекловидность пшеницы яровой урожая 2007 года была 50-51\%.

Для получения хлеба хорошего качества зерно пшеницы должно иметь, по требованию мукомольной и хлебопекарной промышленности, не менее 13-14\% белка и $25 \%$ сырой клейковины, содержание клейковины в муке 70\%-го выхода не менее $30 \%$.

Испытуемые нами сорта озимой тритикале Доктрина 110 и Цекад 90 сформировали зерно с содержанием сырого протеина более $13 \%$. Антей и Гермес $12,4 \%$ и $12,8 \%$ соответственно. Для сравнения: содержание сырого белка в зерне яровой пшеницы на Куединском ГСУ, в зависимости от изучаемых сортов, колебалось от 10,5 до 12,6\%. Аналогичные 
Хлебопекарные качества тритикале озимой, 2008 г.

\begin{tabular}{|c|c|c|c|c|}
\hline \multirow{2}{*}{ Вид анализа } & \multicolumn{4}{|c|}{ Сорт } \\
\hline & Антей-контроль & Гермес & Доктрина 110 & Цекад 90 \\
\hline \multicolumn{5}{|c|}{ Зерновой анализ } \\
\hline Вес 1000 зерен, г & 49,80 & 49,31 & 48,71 & 45,60 \\
\hline Натура, г/л & 721 & 705 & 700 & 706 \\
\hline Число падения, с & 61 & 61 & 61 & 61 \\
\hline Стекловидность зерен, \% & 78 & 58 & 54 & 55 \\
\hline Выход муки, \% & 67 & 67 & 67 & 67 \\
\hline Содержание протеина, \% & 12,8 & 12,4 & 13,1 & 13,2 \\
\hline $\begin{array}{c}\text { Содержание клейковины, \% } \\
\text { из муки }\end{array}$ & 31,2 & 26,0 & 29,0 & 27,6 \\
\hline Упругость клейковины (из муки), усл.ед. & 81 & 76 & 82 & 77 \\
\hline Набухаемость, мл & 29 & 25 & 28 & 37 \\
\hline \multicolumn{5}{|c|}{ Фаринограмма } \\
\hline ВПС (водопоглотител. способность),\% & 68 & 68 & 68 & 63 \\
\hline Время образования теста, мин. & 1,5 & 2 & 2,5 & 1,5 \\
\hline Устойчивость теста, мин. & 0,5 & 0,5 & 0 & 0,5 \\
\hline Разжижение, ед. фрар. & 275 & 210 & 280 & 245 \\
\hline Валориметрическая оценка, ед. вал & 26 & 30 & 27 & 29 \\
\hline \multicolumn{5}{|c|}{ Амилограмма } \\
\hline Начальная температура клейстеризации, $\mathrm{t}_{1}{ }^{\circ} \mathrm{C}$ & 53 & 51 & 51 & 53 \\
\hline $\begin{array}{c}\text { Конечная температура клейстеризации } \mathrm{t}_{2}^{\circ} \mathrm{C} \\
\text { максимальной вязкости, } \mathrm{t}_{2} \mathrm{C} \mathrm{C}\end{array}$ & 64 & 63 & 62 & 73 \\
\hline Максимальная вязкость (h), е.а. & 95 & 115 & 98 & 123 \\
\hline \multicolumn{5}{|c|}{ Хлебопекарная оценка } \\
\hline Объем, мл & 490 & 580 & 550 & 580 \\
\hline -«- балл & 1,4 & 2,3 & 2,0 & 2,3 \\
\hline Поверхность, балл & 3,8 & 4 & 3 & 3 \\
\hline Форма, балл & 4 & 5 & 4,2 & 4,5 \\
\hline Цвет корки, балл & 5 & 4 & 4 & 4 \\
\hline Пористость, балл & 3 & 5 & 4 & 4,5 \\
\hline Структура мякиша, балл & 3 & 4,5 & 4 & 5 \\
\hline Внешний вид, балл & 4,3 & 4,3 & 3,7 & 3,8 \\
\hline Общая оценка, балл & 3,1 & 4,2 & 3,6 & 4,1 \\
\hline
\end{tabular}

данные приводит Е.М. Белоусова (1980), отмечая, что содержание белка в зерне тритикале выше, чем в зерне пшеницы: на сортоучастках разных областей страны Амфидиплоид 206 дал в сравнении со стандартным сортом пшеницы прибавку от 0,1 до $3,1 \%$ [2].

По результатам исследований установлено, что мука из тритикале имеет высокое содержание клейковины - 26,0-31,2\%, но клейковина слабая, удовлетворительного качества, тесто при механической обработке быстро разжижается. Рецептура теста: мука тритикале $67 \%$ выхода - 100 г (влажностью 14\%), дрожжи прессованные - 3 г, соль - 1,5 г, молочная кислота (49\%) 1,0 мл, бромат калия -0,002 г, аскорбиновая кислота $-0,075$ г, вода - 65 мл.
Определен объемный выход хлеба, оценены внешний вид, пористость, эластичность и цвет мякиша по пятибалльной шкале. Внешний вид хлеба оценен по трем показателям: форма, поверхность и цвет корки.

По общей хлебопекарной оценке выделились сорта Гермес - 4,2 и Цекад 90 4,1 балла, у сортов Доктрина 110 и Антей она составила 3,6 и 3,1 балла соответственно. Сорт Гермес имел полуовальную форму корки, гладкую поверхность светло-коричневого цвета, мякиш белого цвета, мелкой структуры, недостаточно ровный, эластичный. Сорт Цекад 90 уступал Гермесу по форме корки (менее выпуклая, шероховатая), пористости мякиша. Мякиш у сорта Цекад 90 желтого цвета. 
У сорта Антей мякиш получился недостаточно эластичным, с неравномерными порами, но имел хороший внешний вид. Сорт Доктрина 110 имел шероховатую поверхность, внешний вид уступал другим сортам. Хлеб у всех сортов тритикале получился ароматный, приятный на вкус. Проведенная дегустация хлеба сотрудниками Пермского НИИСХ также дала высокую оценку сортам Гермес и Цекад 90.

По результатам исследований можно заключить, что мука из тритикале может с успехом использоваться в хлебопекарной промышленности.

\section{Выводы}

1. В Пермском крае появилась перспективная зерновая культура - тритикале, которая с успехом может возделываться в регионе. Это культура универсального использования: зерно пригодно для хлебопечения, в кондитерском производстве, для получения крахмала, спирта, откорма сельскохозяйственных животных. Ее зеленая масса применяется для приготовления гранул, силоса, сенажа, зерносенажа.

2. Используя накопленные запасы влаги за осенне-зимний период, данная куль- тура формирует самый ранний зелёный корм (с конца третьей декады мая до середины июня), обеспечивая высокую урожайность зеленой и сухой массы. Применяя разные по скороспелости сорта тритикале для заготовки кормов, можно обеспечить конвейерное поступление зеленой массы, что позволит раньше начать уборочную кампанию и тем самым снизить нагрузку на технику в пиковые периоды сельскохозяйственных работ.

3. Уборка зеленой массы озимой тритикале в чистом виде и в смеси с озимой викой в начале колошения и в период молочно-восковой спелости зерна обеспечивает высокую урожайность зеленой массы - до 24,5 т/га и сухой массы - 5,96 т/га. Заготовка силоса из свежескошенной зелёной массы озимых культур в начале колошения, зерносенажа в молочно-восковую спелость обеспечивают получение корма I-II класса с содержанием сырого протеина 9,23-18,01\%, обменной энергии 8,73-10,94 МДж/кг, кормовых единиц 0,63-0,97 на абсолютно сухое вещество.

4. При возделывании на зерно урожайность ее достигает 7,18 т/га, в среднем за 2007-2009 гг. она составила 4,54-5,46 т/га.

\section{Библиографический список}

1. Авдусь П.Б., Сапожникова А.С. Определение качества зерна, муки и крупы.- М.: Колос, 1967. - С. $100-160$.

2. Белоусова E.M, Крук Р.В. Хлебопекарные качества тритикале и метод их оценки // Селекция и семеноводство. - 1980. - № 3. - С. 29-31.

3. Беляк В.Б., Бражникова О.Ф. Смешанные посевы в лесостепной зоне Среднего Поволжья // Кормопроизводство. - 1998. - № 9. - С. 6-9.

4. Волошин В.А., Майсак Г.П. Технология возделывания вики озимой в звене кормосырьевого конвейера с использованием отавы на сидерацию. - Пермь, 2006. - 20 с.

5. Государственный реестр селекционных допущенных к использованию. - Т. 1. - М., 2017. - С. 17-18.

6. Грабовеи А.И., Крохмаль А.В. Особенности селекции тритикале на Дону в условиях меняющегося климата // Тритикале: материалы междун. науч-практ. конф. «Роль тритикале в стабилизации производства зерна, кормов и технологии их использования». - Ростов-н/Д, 2014. - С. 37-44.

7. Грабовец А.И.Селекция тритикале на Дону // Тритикале: Материалы 8-й науч.-практ. конф. «Тритикале и стабилизация производства зерна, кормов и продуктов их переработки» 7 июня 2018 г. - Ростов-н/Д, 2018. - С. 7-32.

8. Долгодворов В.Е., Дмитриев М.Я., Горин А.Д., Поздняков Е.П. Продуктивность озимой тритикале в зависимости от величины семян // Зерновое хозяйство. - 2006. - № 1. - С. 22-23.

9. Зарипова Г.К., Ширяев В.М., Биктимиров Р.А. Адаптивные сорта кормовых культур и их семеноводство. - Уфа, 2010. - 22 с.

10. Комаров Н.М., Поспелова Л.С., Соколенко Н.И., Атаманченко П.М. Тритикале - важный резерв кормового поля // Кормопроизводство. - 2002. - № 4. - С. 16-18.

11. Копусь M.M. К 40-летию использования генетического полиморфизма проламинов зерна в селекции и семеноводстве // Тритикале: материалы междун. науч.-практ. конф. «Роль тритикале в стабилизации производства зерна, кормов и технологии их использования». - Ростов-н/Д, 2014. - С. 79-94. 
12. Медведев П.Д., Сметанникова А.И. Кормовые растения Европейской части СССР. - Л.: Колос, 1981. $-335 \mathrm{c}$.

13. Магомедов К.Г., Назранов Х.М., Кумаков Т.Р. Возделывание озимой тритикале на зеленую массу // Земледелие. - 2005. - № 2. - С. 30.

14. Майсак Г.П. Технология возделывания озимой тритикале на зерно и корм для формирования кормосырьевого конвейера, позволяющая получать энергетический корм с КОЭ 10,2-12,1 МДж/кг абсолютно сухого вещества. - Пермь: «ОТ и ДО», 2010. - 24 с.

15. Майсак Г.П. Технология возделывания озимой тритикале в смеси с озимой викой для кормосырьевого конвейера, позволяющая получать корм с концентрацией обменной энергии 10,0-11,6 МДж/кг в сухом веществе и содержанием сырого протеина - 16,6-21,4\%. - Пермь: «ОТ и ДО», 2010. - 24 с.

16. Макарова В.М. Структура урожайности зерновых культур и её регулирование: Пермская ГСХА. Пермь, 1995. - 144 с.

17. Оценка хлебопекарных свойств образцов мягкой пшеницы, ржи и тритикале: метод. указания ВНИИР / под ред. В.И. Комарова. - Л., 1985. - С. 24-28.

18. Результаты сортоиспытания сельскохозяйственных культур на госсортоучастках Пермского края за 2007-2017 гг. - Пермь, 2008.

19. Савчик М.В., Кочурко В.И. Продуктивность и качество зерна озимого тритикале в зависимости от срока скашивания // Зерновое хозяйство. - 2001. - № 1 (4). - С. 30-31.

20. Ступаков И.А., Меркулова Т.Н., Герасименко Л.А. Смешанные посевы кормовых культур // Кормопроизводство. - 1999. - №8. - С. 15-17.

21. Тритикале - первая зерновая культура, созданная человеком: пер. с англ. М.Б. Евгеньева / под общ. ред. Ю.Л. Гужова. - М.: Колос, 1978. - 285 с.

22. Щипак Г.В., Панченко И.А. Биохимические и технологические особенности новых сортов озимой тритикале // Зерновое хозяйство. - 2003. - № 7. - С. 15-17.

23. Фролова Л.В. Продуктивность тритикале озимого при использовании на зелёный корм // Кормопроизводство. - 2002. - № 8. - С. 22-23.

\title{
THE PROSPECTS OF GROWING WINTER TRITICALE IN THE PERM REGION
}

\author{
G.P. Maysak \\ Perm Scientific Research Institute of Agriculture
}

A brief historical note on the creation of a new culture - winter triticale is given. The prospects of the cultivation and use of winter triticale in the Perm region are described. During 2006-2016 the technology of cultivation of winter triticale for fodder and grain in single-species and mixed agrophytocenosis, for the preparation of silage and grain haylage was developed. It has been established that winter triticale is a perspective crop that can be successfully cultivated in the Perm region and can be used for green fodder, silage and grain dumping for harvesting, forming a high yield of both green mass - up to 24,5 tons $/ \mathrm{ha}^{-1}$ and dry weight $-5,96 \mathrm{tons} / \mathrm{ha}^{-1}$, grain -5.46 tons $/ \mathrm{ha}^{-1}$. Silage making from fresh-cut green mass of winter crops at the beginning of the earing, grain load in the milky-wax ripeness produce the forage of the I-II class with the content of crude protein $9,23-18,01 \%$, the exchange energy $-8,73-10,94 \mathrm{MJ} / \mathrm{kg}$, feed units $-0,63-0,97$ per absolutely dry matter.

Keywords: winter triticale, yield, green mass, dry weight, grain, silage, grain haylage.

\section{Сведения об авторе}

Майсак Галина Павловна, кандидат сельскохозяйственных наук, заведующая лабораторией кормопроизводства, животноводства и ветеринарной медицины, Пермский научноисследовательский институт сельского хозяйства - филиал Пермского федерального исследовательского центра УрО РАН (Пермский НИИСХ), 614532, Пермский край, Пермский район, с. Лобаново, ул. Культуры, 12; e-mail: pniish@rambler.ru 